\title{
МОЛОДЕЖЬ КАК ЦЕЛЕВАЯ ГРУППА РR-ПРОЕКТОВ В ИНТЕРНЕТ-КОММУНИКАЦИЯХ
}

\author{
Т. А. Лосева \\ Московский гуманитарный университет
}

Аннотация: В статье рассматривается молодежь как целевая групnа $P R$-проектов, которые распространяются в Интернете.

Ключевыеслова:целеваягруппа;молодежь;интернет-коммуникации; PR-деятельность; Интернет

\section{YOUNG PEOPLE AS A TARGET GROUP OF PR PROJECTS IN INTERNET COMMUNICATIONS}

\author{
T. A. Loseva \\ Moscow University for the Humanities
}

\begin{abstract}
The paper looks upon young people as a target group of PR projects which extend over the Internet.

Keywords: target group; young people; Internet communications; $P R$ activities; Internet
\end{abstract}

В современном обществе активно происходит использование новых информационных технологий. «Сердцем» такого информационного пространства выступает сеть Интернет, доступ к которому обеспечивают различные технические устройства: планшеты, телефоны, ноутбуки и т. д. Интернет соединил множество пользователей между собой, появилось огромное количество сайтов и серверов, посредством которых люди смогли поддерживать между собой связь и производить обмен информацией (Гуров, 2008). Особую среду здесь составляют социальные общественные взаимоотношения - социальные сети (Кошелев, 2013). Особенностью социальных сетей стало то, что они отражают деятельность институтов гражданского общества, в том числе выполняя ряд функций: коммуникативную; информационную; образовательную; транслирующую; регулятивную; интегративную; функцию социализации.

Интернет оказывает непосредственное и доминирующее влияние на гражданское общество и его институты, он как бы «диктует» направление для всего общества, и его роль - огромна. Наиболее активным интернет- 
пользователем или даже так называемым интернет-поколением является молодежь. Под молодежью в данной работе мы понимаем людей в возрасте от 14 до 30 лет. Данная целевая группа имеет высокую степень вовлеченности и участие в интернет-коммуникации. Специфика данной аудитории диктует компаниям и специалистам по связям с общественностью не просто предоставлять те или иные факты, информацию, а организовывать определенные мероприятия, создавать события для того, чтобы молодые люди имели возможность стать их непосредственными участниками. И именно Интернет облегчает эти задачи за счет интерактивности и более целенаправленного общения с данной целевой группой.

Целевая группа является ключевым и определяющим элементом в PR-проекте, трактуясь как определенная группа людей, на которых направлен соответствующий проект (Ших, 2010). По этой причине целевая группа обуславливает ряд целей, задач и технологий PR-проекта.

Ключевые этапы анализа целевых групп следующие:

1) на первом этапе определяются социальные, экономические и демографические показатели, которые имеет целевая аудитория;

2) устанавливается, как целевая аудитория воспринимает объект проектирования, какое мнение имеет и насколько он интересен;

3) выделяются СМИ, к которым у целевой аудитории есть доверие или повышенное доверие;

4) определяются информационные каналы, которые целесообразнее всего использовать в проекте.

Для того, чтобы составить образ, который имеет соответствующая целевая аудитория, следует акцентировать внимание на наличие и особенности следующих ключевых характеристик группы:

1) экономическое положение;

2) социальный статус;

3) половой состав;

4) культурные традиции;

5) информационные потребности;

6) уровень образования и т. д.

Специфика коммуникации с целевой группой в сети Интернет должен стремиться к:

- достижению дружественного и простого общения;

•учету желаний аудитории, особенностей ее восприятия и мышления;

• достижению эмоционального контакта,

- поддержке регулярного и интерактивного общения;

- вовлечению пользователей в процесс взаимодействия в ходе коммуникации (см. также: Скотт, 2013). 
Итак, какова специфика конкретной целевой аудитории - молодежи? Исследователями выделяются ее следующие ключевые черты:

- коммуникация пользователей построена на том, что они обмениваются мгновенными сообщениями и регулярно используют социальные сети;

- получают как правило большую часть новостей через Интернет;

- большее доверие у них вызывают рекомендации других пользователей, чем реклама;

- они ведут собственные страницы в социальных сетях, блогах;

- обладают нетерпеливостью;

- легко действуют, решая одновременно несколько задач;

- обладают совместным мышлением, их деятельность отличается сетевым и коллективным характером;

- отличаются толерантности, которая расширяет коммуникационные горизонты;

- наделены критичностью мышления (Еромолова, 2013).

Молодежь довольно восприимчива ко всему новому, обладает инновативностью, предпочитает технические новинки и высокие технологии. Поэтому и соответствующая информация, где упоминаются новинки, лучше воспринимается данной целевой группой, представляет значительный интерес для нее. В случае же отсутствие в содержании информации о новых технологиях следует использовать более новый, современный и необычный дизайн либо способы ее преподнесения.

Еще одним ключевым отличием, которое характеризует молодежь, является то, что не организация ищет потребителей информации, а сами потребителей осуществляют поиск интересной им информации, молниеносно переключаются между каналами или внутри одного канала информации - переходят с одного поиска на другой, с сайта - на сайт. Поэтому можно сформулировать соответствующую цель PR-специалиста - сделать информацию максимально доступной, чтобы она сначала попала в поле зрение потребителя, а затем заинтересовала его таким образом, чтобы он остановился и ознакомился с ней. При этом важно создать все условия для того, чтобы информация не только заинтересовала пользователя и запомнилась ему, но чтобы он запомнил ту площадку, с которой она была им получена.

Таким образом, можно отметить, что молодежь - важнейшая целевая аудитория именно в интернет-коммуникации особенно, но и в целом она представляет собой довольно значимую целевую аудиторию, поскольку является одним из главных потребителей различной продукции, услуг, товаров. Именно молодежь является «продвинутым» пользователем - это выражается не только в использовании Интернета и социаль- 
ных сетей, но и в ряде других сфер - будь то какой-либо инновационный продукт или новая услуга.

Молодежь выбирает брендовый товар чаще, чем другие группы населения. Невысокая покупательская способность молодежи, тем не менее, не снижает ее уровня осведомленности и потребления брендов. В такой товарной категории, как готовая одежда, молодежь, например, лидирует по уровням информированности и потребления именно брендовой продукции. Молодежь, как правило, выступает новатором в области покупки и применения новых товарных категорий, либо новых торговых марок в уже существующих товарных категориях. Кроме того, приверженность к определенной торговой марке, сформированная в молодости, может остаться у потребителя на всю жизнь (Акчурина, 2011).

Социально-психологические особенности молодежи делают ее одним из привлекательных сегментов на российском рынке готовой модной одежды, техники, ювелирных изделий и т. д. Главная ее часть обучается в вузах, являются студентами. В среднем, студенты проводят на занятиях более пяти с половиной часов ежедневно. Из этого времени более полутора часа они проводят вне аудиторий, общаются между собой, то есть в это время у них происходит прямой контакт с внутренними носителями рекламы, на которых транслируется информация для студентов.

Таким образом, можно сделать следующие выводы. Молодежь как целевая аудитория интернет-коммуникации является одной из ключевых групп для PR-проектов, имеет свои особенности, которые следует учитывать. Учет специфики молодежи как целевой группы и построение в соответствии с этим коммуникации обеспечит эффективность работы PR-специалистов.

\section{СПИСОК ЛИТЕРАТУРЫ}

Акчурина, Е. М. (2011) Молодежь как целевая аудитория современной рекламной компании // Всероссийский журнал научных публикаций. № 5. С. 56-58.

Гуров, Ф. (2008) Продвижение бизнеса в Интернет. Все о PR и рекламе в Сети. М. : Вершина. 136 с.

Ермолова, Н. (2013) Продвижение бизнеса в социальных сетях Facebook, Twitter, Google+. M. : Альпина Паблишер. 357 с.

Кошелев, А. Н. (2013) PR-проектирование, от идеи до воплощения в реальность. М. : Дашков и К. 303 с.

Скотт, Д. (2013) Новые правила маркетинга и PR: как использовать социальные сети, блоги, подкасты и вирусный маркетинг для непосредственного контакта с покупателем. М. : Альпина Паблишер. 349 с. 
Ших, К. (2010) Эра Facebook: как использовать возможности социальных сетей для развития вашего бизнеса. М .: Манн, Иванов и Фербер. 213 с. Дата поступления: 10.06.2017 2.

Лосева Татьяна Александровна - магистрант факультета рекламы Московского гуманитарного университета. Адрес: 111395, Россия, г. Москва, ул. Юности, д. 5. Тел.: +7 (499) 374-67-20. Эл. адрес: tanya26_12@ mail. ru Научный руководитель - д-р ист. н., проф. А. Д. Бородай.

Loseva Tatiana Aleksandrovna, Graduate Student, Department of Advertising, Journalism and Design, Moscow University for the Humanities. Postal address: 5, Yunosti St., Moscow, Russian Federation 111395. Tel.: +7 (499) 374-67-20. E-mail: tanya26_12@mail.ru. Scientific Adviser - A. D. Boroday, Doctor of History, Professor.

\section{Для цитирования:}

Лосева T. А. Молодежь как целевая группа PR-проектов в Интернеткоммуникациях [Электронный ресурс] // Научные труды Московского гуманитарного университета. 2017, № 3. URL: http://journals.mosgu.ru/trudy/article/view/504 (дата обращения: дд.мм.гг.). DOI: 10.17805/trudy.2017.3.10 